\title{
A personal appreciation
}

\author{
Dr Elsie M. Widdowson \\ (22 October 1906-14 June 2000)
}

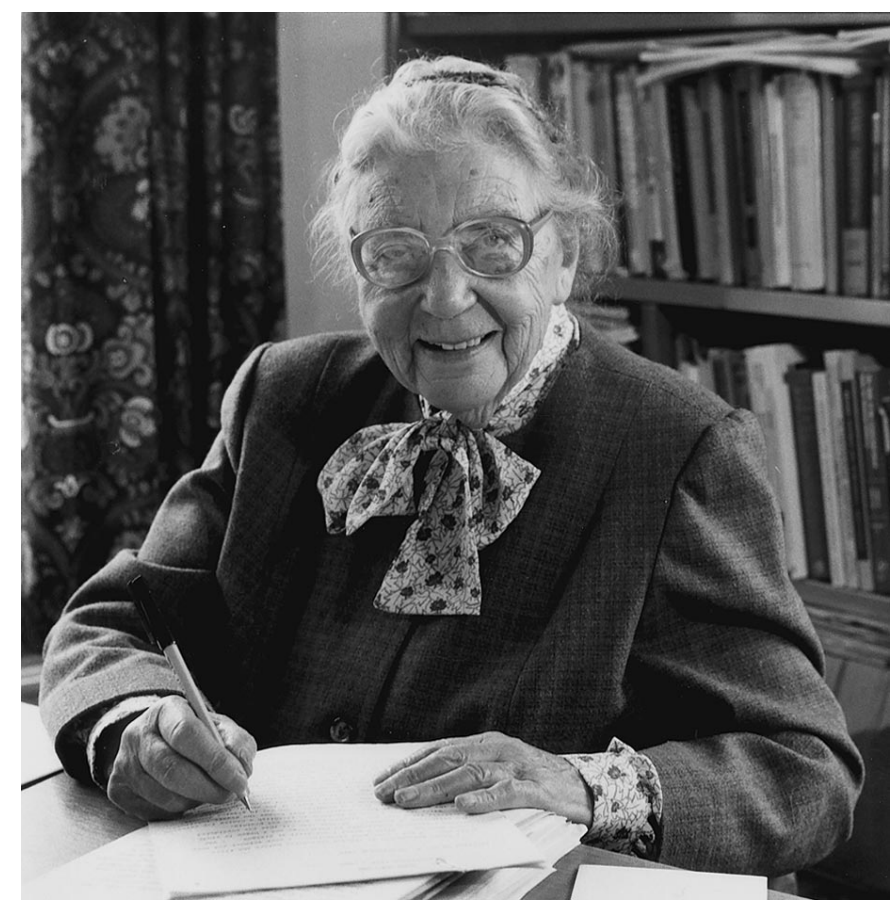

A formal photograph of Dr Widdowson sitting at her desk (which incidentally is untypically tidy). (Photograph taken by Mr David Reed for the National Portrait Gallery, reproduced courtesy of Mr David Reed and Dr Eva Crane.)

The formal milestones of Dr Widdowson's long career have been well-documented, but these serve only as the framework against which to assess her scientific contributions and do not record her human qualities, nor why she was held in such affection by those who came to know and work with her. Dr Widdowson was educated at Sydenham High School where her interests in biological sciences at school were translated into chemistry, which she later went on to read at Imperial College. She continued there for her $\mathrm{PhD}$ studies in which she applied her chemical skills in a study of the changes in the carbohydrates in the developing apple. This was followed by the first brief excursion into research in physiological chemistry with Charles Dodds. Following a suggestion that dietetics was a growth area, she went to King's College Hospital for postgraduate training. This was a fateful and inspired move because she met Dr RA McCance there and this led to a scientific partnership that only ended with his death in 1993.

The special characteristics of their partnership have been well described in Margaret Ashwell's book (Ashwell, 1993).
Their joint work on the composition of foods started with the study of the nutritive value of fruits, vegetables and nuts to complement McCance's work on the composition of flesh foods. This interest in food composition was a means to an end, as I will discuss later.

They moved to Cambridge just before the start of the Second World War, and began to apply their combined biochemical and clinical interests in a range of physiological studies. Professor McCance was a very enquiring clinical scientist which was matched by Dr Widdowson's ability to develop his curiosity into sound experimental studies.

Her many original contributions to physiological science, to the nutritional sciences, and her special contributions to the study of the growth of the foetus and the newborn were recognised in her election to the Royal Society in 1976. A series of other formal honours followed for both partners, many of which Dr Widdowson was genuinely surprised to receive.

In addition to her service on a succession of government committees she made major contributions to the Neonatal 
and Nutrition Societies, being elected President of both and of the British Nutrition Foundation. All these formal milestones of her career are well documented by Margaret Ashwell (1993).

My first recollection of her is when I went to Cambridge for an interview for a post in the Department of Experimental Medicine in the summer of 1955. I saw her drive up and thought 'there goes the secretary', only to be taken later in the afternoon to see her. Fortunately she did not have second sight, and I was offered the post and started working with Dr Ian Holman on the third edition of The Composition of Foods. This involved little contact with Dr Widdowson other than as a rather awe-inspiring figure who sat at the Professor's left hand at 'lab lunch'. Lunch served as a Departmental meeting at which progress with research was discussed, budget requests argued over and at which oral presentations were rehearsed. The vegetables and apples, which regularly formed part of the meal, came from Dr Widdowson's garden. I soon discovered that attendance at lunch was an essential part of working in the Department. Dr Holman had been the biochemist during the bread and other studies in Germany and had some very amusing, but unpublishable, stories of their time there. Ian Holman frequently said that all the easy research problems had been tackled by the 1950s. In many ways it did seem as though McCance and Widdowson had an easy job in picking the best research projects; this view of course has the benefit of hindsight. Dr Widdowson thought that it was probably simpler to get research funding when they started than nowadays. However, I am sure that some special insight was required to pick out profitable research lines in the 1930s, just as it is today.

When Dr Holman left to go to South Africa and I was left in charge of the revision of the third edition of The Composition of Foods I came to work more closely with Dr Widdowson, who proved to be a very demanding boss. She was a very thorough research worker who really had read the literature and understood all the aspects of the study in progress. I learned that attention to detail was essential. To this day I marvel at her ability to spot errors and inconsistencies in tables and woolly texts. Papers went through innumerable versions before she would be satisfied, and her proofreading discipline was exemplary. When I proofread a paper today I still feel a sense of guilt at finding a typographical error. I soon discovered, however, that she was very open to critical comments and would accept argued correction from a colleague 30 years her junior.

Her first major contribution to nutritional science derived from her $\mathrm{PhD}$ studies. In the work on the composition of fruits and vegetables she developed new methods for analysing the individual sugars. In the days before chromatography this was a very difficult task requiring the use of several different reductiometric techniques and then applying simultaneous equations to obtain values for the individual sugars in fruits and vegetables. At a time when most food composition studies were content to measure total carbohydrates 'by difference', her methods enabled the publication of values for sugars and starches. An abbreviated technique was used to measure 'unavailable carbohydrate' (later known as dietary fibre), in the 1930s!
She was very jubilant when she observed that the values for the individual sugars in foods using the latest HPLC methods were very similar to her earlier results.

One must also remember that all colorimetric methods had then to be made by matching colours by eye. In the Department of Experimental Medicine I found a Klett Colorimeter at the back of a cupboard and my respect for her analytical techniques increased when I tried to use it.

Analysis and food composition were however a means to an end. The semi-micro methods devised for inorganic constituents provide powerful tools for studying nutrient bioavailability of minerals which formed the next major contribution that she and McCance made.

The separate roles in the partnership are difficult to disentangle. When asked who first thought of this or that, they both were at a loss to assign credit. This extended into their writing, where unlike most collaborating authors they seemed to write as one.

They made major advances in the understanding of $\mathrm{Fe}$ bioavailability, including an attempt to measure haem-Fe. Their studies on $\mathrm{Ca}$ bioavailability led to identification of the key role of phytic acid as an inhibitor of absorption. They worked through the periodic table in their studies of excretion of elements using themselves as experimental subjects. After the war when atomic fallout became a matter of concern, those involved were surprised that McCance and Widdowson had studied the excretion of $\mathrm{Sr}$ in the late 1930s.

Dr Widdowson quickly recognised the potential use of Food Composition Tables and carried out one of the first major studies of the diets of children. She studied 1000 subjects, and those used to doing dietary analyses with computerised databases should be full of wonder at the prospect of the calculations involved with only slide rules and $\log$ tables as the calculation aids.

The same analytical skills were extended to the study of the composition of the human body, another very difficult and exacting piece of work.

Dr Widdowson asked me at our first meeting 'was I afraid of hard work?'. It is obvious that she was not, and many scientific questions that deserved attention were undertaken by McCance and Widdowson, even though they had daunted others. In these Dr Widdowson was the experimental designer and facilitator.

When I joined the Department in 1955 they were in the process of completing the publication of work undertaken in Germany after the end of the war, and considering the implications of the effects of different types of bread on the growth of the children in two orphanages. It was typical of Dr Widdowson that she noticed that the children grew better in the orphanage that had a kindly matron than in the orphanage where the matron established a strict and severe regime. The observation suggested an interaction between nutrition and psychological factors. The observation was reinforced when the German authorities obligingly, but unwittingly, exchanged the two matrons between the orphanages, thus providing a very elegant crossover design that confirmed the hypothesis.

The work in Germany was a classic example of tackling a major piece of work logistically, as well as scientifically, because it was the only way of getting the answers that 
were needed. Dr Widdowson was very scathing of those who attempted to answer questions of human nutrition by studies on mice, although she was well aware of the important contribution that animal studies could make.

Setting up the analytical repertoire for the work on the revision of the third edition of The Composition of Foods in the 1950 s provided another means to an end, and many parallel studies using the same analytical methods were carried out alongside the food analysis. We had the advantage of instrumental methods which were coming into use at that time, and Dr Widdowson frequently remarked to me that with all these advantages we did not seem to be producing results any quicker than she had!

The studies on growth during periods of undernutrition fascinated both McCance and Widdowson, and she initiated some studies on fetal growth with Christine Spray which I later continued.

She also became interested in infant nutrition, which in the early 1960s seemed to be of little interest to many paediatricians. I was assigned to supervise the laboratory work of PhD students and 'Post Docs' working with her at this time, and eventually became more personally involved with studies of various infant formulas with her. She had a wide ranging interest in comparative nutrition and the lessons one could learn from it. We explored the composition of milks from a range of primates and large animals such as elephant and hippopotamus. The work with the primate milks was not started out of mere curiosity, but to provide information to the Bristol Zoo. The Zoo had an active primate breeding programme and needed guidance on formulating milk substitutes, because many of the primate dams often seemed to have no interest in feeding their young.

This interest in growth and the physiological demands it placed on the young animal, and the implications for the nutritional requirements of the young fascinated her. Whilst I was Editor of the British Journal of Nutrition she wrote telling me about some studies of the nutrition of young bears, asking whether it would interest the British Journal of Nutrition even though the numbers of animals studied could never reach the normal statistical requirements of the journal. The results looked fascinating and a rare insight into a stage of life not very amenable to study, and the paper duly appeared.

An abiding characteristic of Dr Widdowson was her interest in new areas that advanced human and especially infant nutrition, an interest that remained with her until she died.

What about Dr Widdowson as a person? First, as a boss she expected commitment and acceptance of responsibility. She was exacting, especially when preparing papers for publication, but equally when an oral presentation was required. When she gave a paper she did not seek to impress the audience with her knowledge and wisdom, she wanted them to follow and understand the work she was presenting. She had mastered the art of reading a typescript while at the same time appearing to be speaking without notes. I realised later that this was due to three things: first, writing very clearly in simple explicit language, phrased in short sentences; second, organising her text so that readable phrases of text were separated (which of course depended

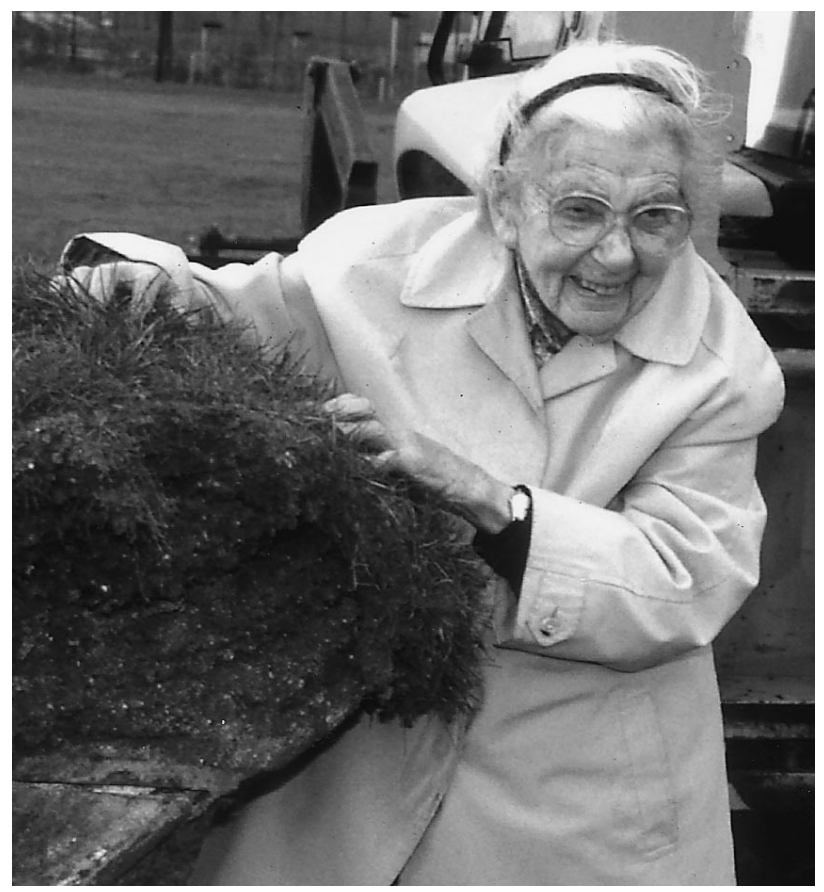

This photograph shows her delight at cutting the first sod for the new Elsie Widdowson Laboratory in Cambridge. (Medical Research Council Visual Aids, Cambridge, UK.)

on a sensitive secretary); third, the discipline of rehearsing the presentation.

She was a devout Christian, and her knowledge of the Bible is much in evident in the quotations that often appeared in her papers. She delighted in pointing out the first published account of a nutrition study (Daniel 1, 1116) recognised the need for a control group!

Dr Widdowson was very ready to make sure that her junior colleagues received proper credit for their contributions, and would take them with her to committee meetings if they had done preparatory work for her contribution to the committee.

She had that special facility of treating everyone she met with courtesy, and was at home with the highest in the land and the most junior technician.

As I began to work with her more closely I saw a warm personality who especially enjoyed picnics and who took a grandmotherly delight in the families of her colleagues.

Finally, three personal memories of Dr Widdowson remain. First, her gentle chiding asking me how old I was, when an early paper of hers that I had criticised, was published. Second, in the late 1970s, her telephoning her mother, as a dutiful daughter, to tell her she would be late home, when we were delayed in London, and third, leading my young children on a fishing expedition in the stream at the bottom of her garden in Barrington.

It was a privilege to know and work with her.

David Southgate

\section{References}

Ashwell M (editor) (1993) McCance \& Widdowson. A Scientific Partnership of 60 Years, 1933-1993. London: British Nutrition Foundation. 